\title{
SEASONAL VARIABILITY OF PHYSICOCHEMICAL PARAMETERS OF WATER QUALITY ON LENGTH OF USZWICA RIVER
}

\author{
Andrzej Bogdał', Tomasz Kowalik', Krzysztof Ostrowski', Patrycja Skowron ${ }^{1}$
}

1 Department of Land Reclamation and Environmental Development, University of Agriculture in Krakow, Al. Mickiewicza 24-28, 30-059 Krakow, Poland, e-mail: rmbogdal@cyf-kr.edu.pl; rmkowali@cyf-kr.edu.pl; rmostrow@cyf-kr.edu.pl; pathiskowron@gmail.com

Received: 2015.10 .27

Accepted: 2015.12.09

Published: 2016.01.06

\begin{abstract}
The Uszwica river catchment is located in the central part of Lesser Poland province, within Brzeski and Bocheński districts. The river is $61.2 \mathrm{~km}$ long, and its catchment area is $322.5 \mathrm{~km}^{2}$. It is characterized by forest-agricultural land use and high share of residential areas of both compact (the city of Brzesko) and dispersed nature. In the abiotic terms, the Uszwica in its upper course may be classified as a flysch stream (type 12). From the moment of joining the Niedźwiedź, stream until its discharge into the Vistula at $\mathrm{km} \mathrm{151+700} \mathrm{it} \mathrm{is} \mathrm{a} \mathrm{sand} \mathrm{and} \mathrm{clay} \mathrm{lowland} \mathrm{river} \mathrm{(type} \mathrm{19).} \mathrm{Hydrochemical} \mathrm{research} \mathrm{were}$ conducted in the years 2011 and 2012 at two measurement-control points - one located near the mouth of the river (point 1) and one located about $7.5 \mathrm{~km}$ downstream from the city of Brzesko (point 2). Each month 18 water quality parameters were determined and they underwent comparative and statistical analyses. Basic descriptive statistics were calculated for both measurement-control points. Then, they were used to determine the ecological potential of the river and to evaluate water quality parameters with respect to its suitability as fish habitat and eutrophication risk. Significance of differences between the values of individual parameters recorded at different measurement-control points was estimated using non-parametric Mann-Whitney $U$ test for $\alpha=0.05$. The same test was used to determine the significance of differences between individual parameters for the winter and summer season at each point. Analysis of the results revealed that water flowing via developed areas (point 2) was significantly less saturated with oxygen and contained higher amounts of suspended solids, organic matter and nutrients, as compared to the section of the river flowing mainly through extensively used agricultural areas. Therefore, the ecological potential of the river was considered good in its lower course and poor upstream from point 2. Disturbances in seasonal concentrations of some biogenic factors indicated high degree of water pollution in the middle course of the Uszwica. However, due to intense self-purification, water quality in the lower course was similar to that in natural conditions. On the entire investigated section of the Uszwica does not meet water quality requirements for salmonids and cyprinids, but the habitats are more favorable near the mouth of the river. Water assessed at point 2 may be classified as eutrophic due to high concentration of total phosphorus.
\end{abstract}

Keywords: ecological potential, water pollution, physicochemical indices, eutrophication.

\section{INTRODUCTION}

Water is a specific and common natural resource indispensable for all living organisms. It is both exhaustible and renewable resource, as when depleted or excessively polluted in a given place and time, its quantity and quality can be restored in favorable conditions. The problem of water pollution is usually perceived only when clean water is required [Chełmicki 2001]. The quality of surface waters, both stagnant and flowing, is very important to humans and natural environ- 
ment and thus it should meet specific biological, physical, chemical and microbiological requirements [Kanownik and Rajda 2011, LampartKałużniacka et al. 2012, Napieralska and Gołdyn 2013]. Therefore, maintaining proper water status is becoming increasingly important [Directive 2000/60/EC].

Human activity often negatively affects natural environment, including its water domain. Previous studies showed that water leaving the catchments located in developed and suburban areas, especially highly urbanized ones, is of poorer quality as compared to water leaving forest areas or extensively used farmlands [Ostrowski et al. 2011, Bogdał and Ostrowski 2009, Kanownik et al. 2011, Wiatkowski et al. 2012, Húska et al. 2013, Policht-Latawiec et al. 2014]. This particularly pertains to biogenic pollutions discharged with municipal wastewater. Numerous authors showed that most factors related to the type of catchment land use significantly affect concentration of some chemicals in water [Żmuda et al. 2001, Dąbrowska 2008, Pokładek and Nyc 2008, Kleiber 2012, Kowalik et al. 2012]. Degree of pollution in developed catchments was also observed to increase along the watercourse. This is often caused by a lack of a sewage system or inefficient wastewater treatment plants [Moniewski and Stolarska 2007]. As there are many different sources of pollution, the potential of water to be reclaimed and to restore its quality, different for various forms and types of environmental water, is amazing. Due to its nature and constant rotation, flowing water is most quickly reclaimed as a result of intense self-purification [Bogdał et al. 2012, Policht-Latawiec et al. 2015] that is a set of complex physical and chemical processes lowering the concentration of dissolved chemicals.

The aim of the study was to evaluate seasonal changes in the concentration and range of selected physicochemical parameters of water in the Uszwica river. To this end, comparative and statistical analyses were performed that comprised hydrochemical data collected for two years at two measurement-control points.

\section{MATERIAL AND METHODS}

The investigated river Uszwica is $61.2 \mathrm{~km}$ long and its catchment is located in the central part of Lesser Poland province, within Brzeski and Bocheński districts. Its sources can be found on the northern slopes of Island Beskids, near Rajbrot at the foot of the Kobyla Góra. After leaving the Beskids slopes, the river crosses Wiśnicz Foothills, and belows Brzesko it enters Bochnia Foothils and then the Vistula Lowlands. Near Wola Przemykowska the Uszwica enters the Vistula on its right bank at km 150+700 (Figure 1).

In the abiotic terms, the Uszwica in its upper course may be classified as a flysch stream of type 12. From the moment of joining the Niedźwiedź stream until the mouth of the Vistula it is a sand and clay lowland river of type 19. The greatest right-bank tributaries of the Uszwica are Niedźwiedź, Grodna, Borowa Struga, and Wróblówka, and left-bank ones include Leksandrówka, Potok Górzański, and Korytnica. All these watercourses are supplied by numerous unnamed tributaries, which in the lower course of the Uszwica are mainly drainage ditches.

The Uszwica catchment with the area of 322.5 $\mathrm{km}^{2}$ belongs to the water region of the upper Vistula. The cities and villages located in the catchment include Brzesko with 17 thousand inhabitants, Jadowniki (5 thousand), Borzęcin (nearly 4 thousand), Gnojnik and Poręba Spytkowska (each ca. 2.5 thousand), Szczurowa (2 thousand), Bielcza (1.6 thousand), Lipnica Murowana with about one thousand inhabitants and a number of smaller villages. Large population inhabiting the catchment area and ineffective wastewater management resulted in making the Uszwica a receiver of domestic and municipal wastewater. The city of Brzesko that produces the greatest amount of wastewater and treated water is located in the middle course of the river.

The Uszwica catchment is covered mainly by Quaternary sediments comprising sands, glacial gravels and outwash tills. Bedrock located on this substrate yielded hardly fertile podzols and luvisols as well as eutric and dystric cambisols. Accumulation of river deposits along watercourses yielded gleyic soils and fluvisols. In terms of land use, it is a forest-agricultural catchment with high share of built-up areas. Over $35 \%$ of the catchment is covered with forests growing on the slopes of the Island Beskids and Wiśnicz Foothills. Farmlands constitute $50 \%$ of the catchment area and are located mainly in its central and northern part. Built-up areas account for over $13 \%$ of the area, and therefore, the catchment may be classified as a wellsealed and anthropogenically transformed one.

The hydrochemical analysis focused on the range and concentration of physicochemical 


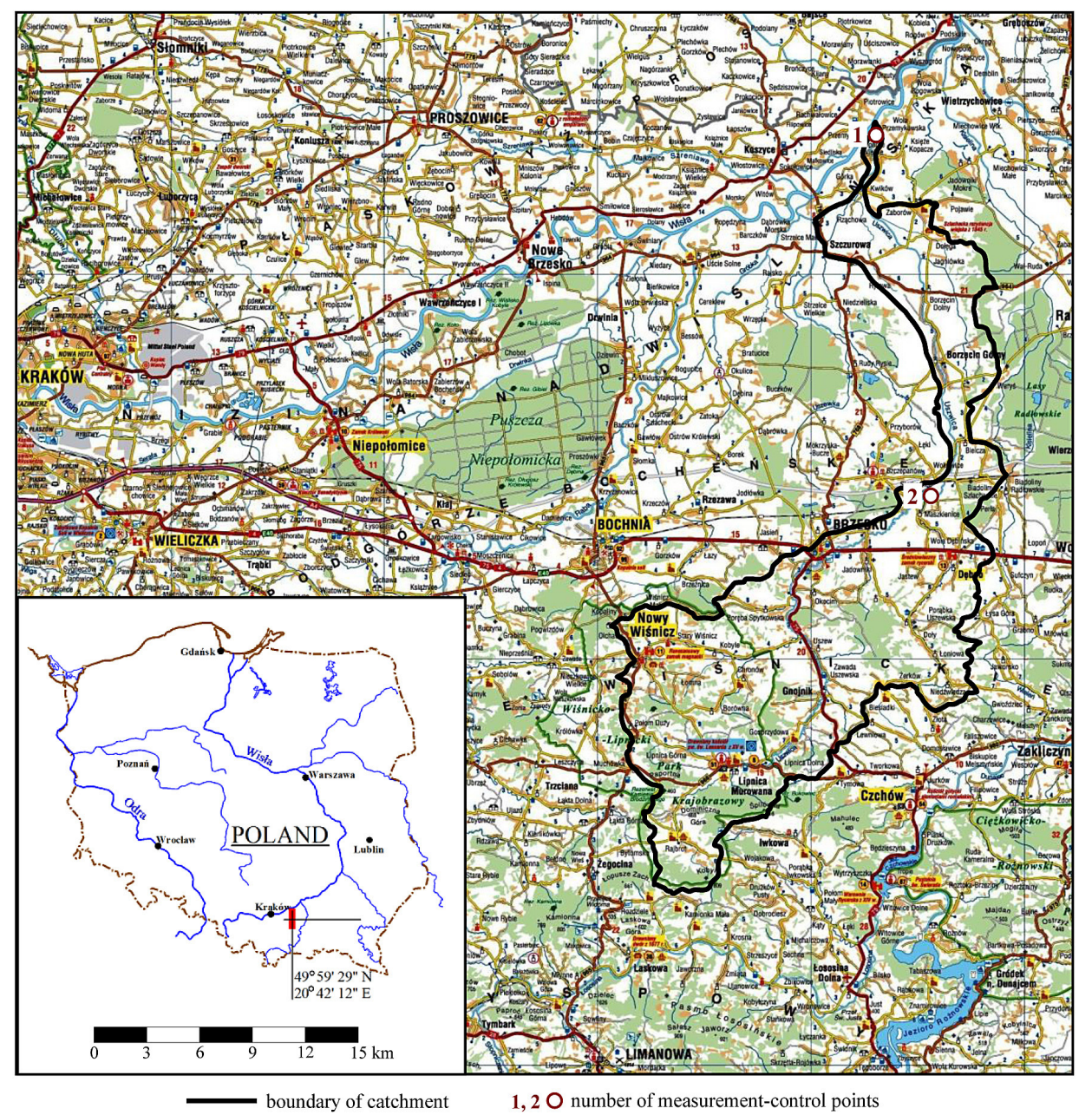

Figure 1. Localization of the Uszwica catchment

quality-related parameters of the Uszwica water investigated in the years 2011 and 2012. Water samples were collected at two measurementcontrol points. The first one, encompassing the whole catchment was located about $600 \mathrm{~m}$ from the Uszwica discharge into the Vistula in Wola Przemykowska (point 1), and the second was located in Maszkienice, about $7.5 \mathrm{~km}$ downstream from the city of Brzesko, at $26+500 \mathrm{~km}$ (point 2 ) and encompassed the upper part of the catchment with the area of $249.3 \mathrm{~km}^{2}$. Upstream from point 2, the Uszwica crosses built-up areas and the section between the measurement-control points is covered mainly by extensively used farmlands.

Each month 18 water quality parameters were determined using standard methods [Regulation of the Minister of the Environment, 2011] and they underwent comparative and statistical analyses. Basic descriptive statistics were worked out for each water quality parameter for each station for the whole study period (2011-2012) and with breakdown into the winter (October-March) and summer (April-September) period. Nine selected parameters were presented in box plots with breakdown into stations, seasons, median, extreme values of $10-90 \%$ percentiles. Significance of differences between the values of individual parameters recorded at different measurementcontrol points was estimated using non-parametric Mann-Whitney U test for $\alpha=0.05$. The same test was used to determine the significance of differences between individual parameters for the winter and summer season at each point. Nonparametric Mann-Whitney U test was employed for the statistical analysis of the collected data, as many compared groups did not follow normal distribution as per Shapiro-Wilk test or heterogeneity of variance as per Brown-Forsythe test. Mean values were used to determine the ecological potential [Regulation of the Minister of the Environment 2014] and trophic state index [Regulation of the Minister of the Environment $2002 \mathrm{~b}]$ of the water and raw data were used to assess fish habitat usability [Regulation of the Minister of the Environment 2002a]. 


\section{RESULTS}

Water temperature in the Uszwica at both measurement-control points did not exceed that defined for first class water, i.e. $22^{\circ} \mathrm{C}$. The only exception was a single recording from 1st June 2012 at the point 1 , when the temperature was $0.6^{\circ} \mathrm{C}$ above the limit. Mean water temperature at the points 1 and 2 was similar and amounted to $10.0^{\circ} \mathrm{C}$ and $9.6^{\circ} \mathrm{C}$, respectively. Based on the temperature range, the investigated water belonged to the first class (Table 1). Mean concentration of suspended solids at point 1 and 2 was 30.6 and $59.0 \mathrm{mg} \cdot \mathrm{dm}^{-3}$, respectively, which means the limit value for the first class $\left(25 \mathrm{mg} \cdot \mathrm{dm}^{-3}\right)$ was exceeded in both cas- es. The first concentration corresponded to good ecological potential and the second indicated poor ecological potential. Similarly as the temperature, the concentration of suspended solids was comparable at both measurement-control points. High coefficient of variation (over 60\%) indicated high degree of random variation for these physical parameters (Table 1). The intense dynamics of temperature fluctuations may be partly explained by seasonal changes in air temperature. The changes in suspended solids were brought about by their incidental but very high concentrations associated with erosion processes occurring after intense rainfalls, especially in the upper part of the catchment characterized by more variable terrain.

Table 1. Selected descriptive statistics of physicochemical indicators of water quality, results of assessment the significance of differences between the values of measurement-control points and water quality in the Uszwica river

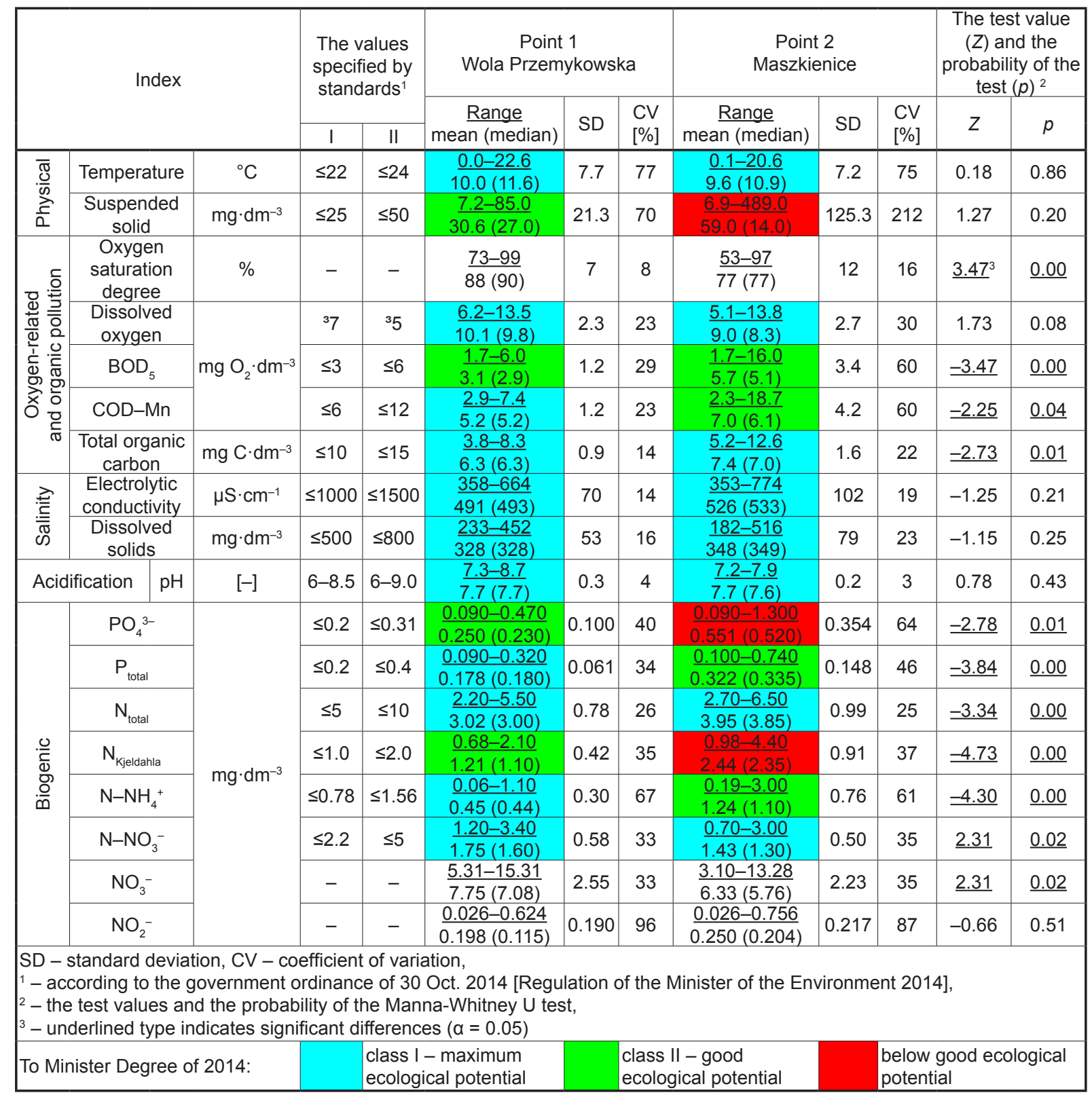


Concentration of dissolved oxygen within the investigated section of the Uszwica ranged from 5.1 to $13.8 \mathrm{mg} \mathrm{O}_{2} \cdot \mathrm{dm}^{-3}$. Mean values at point 1 and 2 were 10.1 and $9.0 \mathrm{mg} \mathrm{O}_{2} \cdot \mathrm{dm}^{-3}$, respectively, and exceeded the minimum of $7.0 \mathrm{mg} \mathrm{O} \cdot \mathrm{dm}^{-3}$, thus meeting the requirements for the first class. Water oxygen saturation was more variable, as mean and median values at the mouth of the river were by $11 \%$ and $13 \%$ higher than in its upstream course. Dissolved oxygen concentrations were similar at the point 1 and 2 but significant differences in oxygen saturation were confirmed by Mann-Whitney $U$ test (Table 1). Higher oxygen concentration between Maszkienice and Wola Przesmykowska was mainly due to lower human pressure in the lower course of the river. Another reason is the fact that longitudinal slope of the Uszwica upstream from the point 2 is much steeper than in the rest of its course, and under undisturbed conditions this should translate into higher water saturation with oxygen. Random differentiation of dissolved oxygen concentration was low $(\mathrm{CV}<20 \%)$, and oxygen saturation was moderate - coefficient of variation ranged from $21 \%$ to $40 \%$ (Table 1 ).

At the second measurement-control point located in Maszkienice, mean $\mathrm{BOD}_{5}$ and COD-Mn and total organic carbon were 5.7, 7.0 $\mathrm{mg} \mathrm{O}_{2} \cdot \mathrm{dm}^{-3}$ and $7.4 \mathrm{mg} \mathrm{C} \cdot \mathrm{dm}^{-3}$, respectively. These values were by $84 \%, 35 \%$ and $18 \%$ higher than those recorded at the point near the Uszwica discharge into the Vistula. Mean $\mathrm{BOD}_{5}$ at both points indicated second class of water purity, and mean total carbon concentration did not exceed the limit for the first class, i.e., $10 \mathrm{mg} \mathrm{C} \cdot \mathrm{dm}^{-3}$. In terms of COD-Mn, water at the point 1 reflected the best possible ecological potential and at the point 2 it met the requirements for the second class (Table 1). Mean, maximum and median values for these three indicators of organic pollution were always higher at the point located just below Brzesko, which was undoubtedly caused by discharge of municipal wastewater into surface waters. Due to irregular supply of pollution from anthropogenic sources, the concentrations of $\mathrm{BOD}_{5}, \mathrm{COD}-\mathrm{Mn}$ and total organic carbon at the point 2 were highly variable, as manifested by significantly higher coefficient of variation than in point 1 (Table 1).

Typical values of two assessed salinity indicators, i.e., electrolytic conductivity and the dissolved solids, were very similar for both measurement-control points, as confirmed statistically at $\alpha=0.05$. Mean electrolytic conductivity was nearly 2 times, and mean dissolved solids concentration about 1.5 times lower than the limit for the first class. Salinity was very stable along the entire investigated length of the Uszwica, as the coefficient of variation ranging from $14 \%$ to $23 \%$ indicated small or moderate variability in the recorded data (Table 1).

$\mathrm{pH}$ of the investigated water ranged from slightly to strongly alkaline and it was $7.3-8.7$ in point 1 and $7.2-7.9$ in point 2 . Average $\mathrm{pH}$ in both points was identical (7.7) and met the criteria for the first class. Coefficient of variation was also similar and very low (3-4\%), indicating low dynamics of the recorded data (Table 1).

The biogenic indicators estimated in the Uszwica water included phosphates, phosphorus and total nitrogen, Kjeldahl nitrogen, ammonium and nitrate nitrogen and nitrates and nitrites. Except for $\mathrm{N}-\mathrm{NO}_{3}^{-}$and $\mathrm{NO}_{3}^{-}$, mean and median concentrations of all other indicators were markedly higher at point 2 . This indicated greater pollution at the point 2 and active self-purification processes in the water reaching the point 1 , when, as a result of nitrification, organic and ammonium nitrogen were reduced and nitrate content increased. Differences in the concentration of all parameters but $\mathrm{NO}_{2}{ }^{-}$, recorded at individual stations, were significant (Table 1). Water reaching the point 2 did not meet the requirements for the second class due to mean concentration of $\mathrm{PO}_{4}^{3-}$ and Kjeldahl nitrogen, whereas downstream the concentration of phosphates and Kjeldahl nitrogen decided on good ecological potential of water at the point 1 . Coefficient of variation depended on the investigated parameter and ranged from $25 \%$ to $96 \%$, indicating moderate, large or even very large variability in the concentration of biogenic substances (Table 1).

Seasonal variability of water quality indicators may indirectly indicate pollution, if certain processes occurring in clean waters are disturbed. Air temperature is the factor most effectively determining seasonal changes of water quality indicators. It also affects plant growth, oxygen solubility and intensity of chemical and biochemical processes.

Some indicators showed a lack of seasonal variation at either measurement-control point, as confirmed by statistical analyses at $\alpha=0.05$. They included suspended solids, $\mathrm{BOD}_{5}$, total organic carbon, $\mathrm{pH}$, electrical conductivity, dissolved solids, total phosphorus and Kjeldahl nitrogen (Table 2, Figure 2). 
Table 2. Water quality parameters in the winter and summer season - means and medians, test results $(Z)$ and test probability $(p)$ of Mann-Whitney U test

\begin{tabular}{|c|c|c|c|c|c|c|c|c|c|}
\hline \multirow{3}{*}{ Index } & \multirow{3}{*}{ Unit } & \multicolumn{4}{|c|}{ Point 1 - Wola Przemykowska } & \multicolumn{4}{|c|}{ Point 2 - Maszkienice } \\
\hline & & \multicolumn{2}{|c|}{$\begin{array}{c}\text { Mean } \\
\text { (median) }\end{array}$} & \multicolumn{2}{|c|}{$\begin{array}{c}\text { Results of the test in } \\
\text { the variant } \\
\text { Winter-Summer }\end{array}$} & \multicolumn{2}{|c|}{$\begin{array}{c}\text { Mean } \\
\text { (median) }\end{array}$} & \multicolumn{2}{|c|}{$\begin{array}{c}\text { Results of the test in } \\
\text { the variant } \\
\text { Winter-Summer }\end{array}$} \\
\hline & & Winter & Summer & Z & $\mathrm{p}$ & Winter & Summer & $Z$ & $p$ \\
\hline Temperature & ${ }^{\circ} \mathrm{C}$ & $\begin{array}{c}3,2 \\
(1,4)\end{array}$ & $\begin{array}{c}16,9 \\
(16,9)\end{array}$ & $-4,13^{1}$ & $\underline{0,00}$ & $\begin{array}{c}3,2 \\
(1,7)\end{array}$ & $\begin{array}{c}15,9 \\
(16,2)\end{array}$ & $-4,13^{1}$ & $\underline{0,00}$ \\
\hline Suspended solids & $\mathrm{mg} \cdot \mathrm{dm}^{-3}$ & $\begin{array}{c}24,2 \\
(20,0)\end{array}$ & $\begin{array}{c}37,0 \\
(37,5)\end{array}$ & $-0,93$ & 0,36 & $\begin{array}{c}23,7 \\
(14,0)\end{array}$ & $\begin{array}{c}94,2 \\
(15,0)\end{array}$ & $-1,07$ & 0,29 \\
\hline $\begin{array}{c}\text { Oxygen saturation } \\
\text { degree }\end{array}$ & $\%$ & $\begin{array}{c}91 \\
(93)\end{array}$ & $\begin{array}{c}85 \\
(83)\end{array}$ & $\underline{2,49}$ & $\underline{0,01}$ & $\begin{array}{c}85 \\
(88)\end{array}$ & $\begin{array}{c}68 \\
(69)\end{array}$ & $\underline{3,24}$ & $\underline{0,00}$ \\
\hline Dissolved oxygen & \multirow{3}{*}{$\mathrm{mg} \mathrm{O}_{2} \cdot \mathrm{dm}^{-3}$} & $\begin{array}{c}12,1 \\
(12,5)\end{array}$ & $\begin{array}{c}8,1 \\
(8,0)\end{array}$ & $\underline{4,13}$ & $\underline{0,00}$ & $\begin{array}{c}11,2 \\
(11,7)\end{array}$ & $\begin{array}{c}6,8 \\
(6,6)\end{array}$ & $\underline{3,87}$ & $\underline{0,00}$ \\
\hline $\mathrm{BOD}_{5}$ & & $\begin{array}{c}3,3 \\
(3,1)\end{array}$ & $\begin{array}{c}2,9 \\
(2,4)\end{array}$ & 1,07 & 0,29 & $\begin{array}{c}5,6 \\
(5,1)\end{array}$ & $\begin{array}{c}5,8 \\
(5,1) \\
\end{array}$ & $-0,40$ & 0,69 \\
\hline COD-Mn & & $\begin{array}{c}4,5 \\
(4,7)\end{array}$ & $\begin{array}{c}5,9 \\
(5,8)\end{array}$ & $-2,91$ & $\underline{0,00}$ & $\begin{array}{c}6,1 \\
(6,0)\end{array}$ & $\begin{array}{c}7,9 \\
(6,3)\end{array}$ & $-0,64$ & 0,53 \\
\hline Total organic carbon & $\mathrm{mg} \mathrm{C} \cdot \mathrm{dm}^{-3}$ & $\begin{array}{c}6,1 \\
(6,1)\end{array}$ & $\begin{array}{c}6,6 \\
(6,5)\end{array}$ & $-1,07$ & 0,28 & $\begin{array}{c}7,3 \\
(6,9)\end{array}$ & $\begin{array}{c}7,5 \\
(7,3)\end{array}$ & $-0,95$ & 0,34 \\
\hline $\mathrm{pH}$ & {$[-]$} & $\begin{array}{c}7,7 \\
(7,7) \\
\end{array}$ & $\begin{array}{c}7,8 \\
(7,7)\end{array}$ & $-0,68$ & 0,50 & $\begin{array}{c}7,7 \\
(7,7) \\
\end{array}$ & $\begin{array}{c}7,6 \\
(7,6)\end{array}$ & 1,94 & 0,05 \\
\hline $\begin{array}{l}\text { Electrolytic } \\
\text { conductivity }\end{array}$ & $\mu \mathrm{S} \cdot \mathrm{cm}^{-1}$ & $\begin{array}{c}477 \\
(509)\end{array}$ & $\begin{array}{c}504 \\
(486)\end{array}$ & $-0,26$ & 0,80 & $\begin{array}{c}514 \\
(521)\end{array}$ & $\begin{array}{c}538 \\
(533)\end{array}$ & $-0,23$ & 0,82 \\
\hline Dissolved solids & \multirow{9}{*}{$\mathrm{mg} \cdot \mathrm{dm}^{-3}$} & $\begin{array}{c}320 \\
(331)\end{array}$ & $\begin{array}{c}335 \\
(326)\end{array}$ & $-0,66$ & 0,51 & $\begin{array}{c}353 \\
(354)\end{array}$ & $\begin{array}{c}342 \\
(334)\end{array}$ & 0,49 & 0,62 \\
\hline $\mathrm{PO}_{4}^{3-}$ & & $\begin{array}{c}0,221 \\
(0,225)\end{array}$ & $\begin{array}{c}0,278 \\
(0,250)\end{array}$ & $-1,04$ & 0,30 & $\begin{array}{c}0,416 \\
(0,345)\end{array}$ & $\begin{array}{c}0,686 \\
(0,670)\end{array}$ & $-2,06$ & $\underline{0,04}$ \\
\hline$P_{\text {total }}$ & & $\begin{array}{c}0,175 \\
(0,165)\end{array}$ & $\begin{array}{c}0,181 \\
(0,185)\end{array}$ & $-0,23$ & 0,82 & $\begin{array}{c}0,292 \\
(0,240)\end{array}$ & $\begin{array}{c}0,353 \\
(0,360)\end{array}$ & $-1,68$ & 0,09 \\
\hline $\mathrm{N}_{\text {total }}$ & & $\begin{array}{c}3,33 \\
(3,10)\end{array}$ & $\begin{array}{c}2,70 \\
(2,40)\end{array}$ & $\underline{2,06}$ & $\underline{0,04}$ & $\begin{array}{c}4,26 \\
(4,10)\end{array}$ & $\begin{array}{c}3,64 \\
(3,30)\end{array}$ & 1,42 & 0,16 \\
\hline $\mathrm{N}_{\text {Kjeldahl }}$ & & $\begin{array}{c}1,31 \\
(1,20)\end{array}$ & $\begin{array}{c}1,11 \\
(0,98)\end{array}$ & 1,31 & 0,19 & $\begin{array}{c}2,56 \\
(2,45)\end{array}$ & $\begin{array}{c}2,32 \\
(1,95)\end{array}$ & 0,46 & 0,64 \\
\hline $\mathrm{N}-\mathrm{NH}_{4}^{+}$ & & $\begin{array}{c}0,58 \\
(0,58)\end{array}$ & $\begin{array}{c}0,31 \\
(0,23)\end{array}$ & $\underline{2,17}$ & $\underline{0,03}$ & $\begin{array}{c}1,27 \\
(1,10)\end{array}$ & $\begin{array}{c}1,21 \\
(1,07)\end{array}$ & 0,46 & 0,64 \\
\hline $\mathrm{N}-\mathrm{NO}_{3}^{-}$ & & $\begin{array}{c}2,01 \\
(1,75)\end{array}$ & $\begin{array}{c}1,49 \\
(1,55)\end{array}$ & $\underline{2,19}$ & $\underline{0,03}$ & $\begin{array}{c}1,68 \\
(1,55)\end{array}$ & $\begin{array}{c}1,19 \\
(1,25)\end{array}$ & $\underline{2,27}$ & $\underline{0,02}$ \\
\hline $\mathrm{NO}_{3}^{-}$ & & $\begin{array}{c}8,89 \\
(7,75)\end{array}$ & $\begin{array}{c}6,60 \\
(6,86)\end{array}$ & $\underline{2,19}$ & $\underline{0,03}$ & $\begin{array}{c}7,42 \\
(6,87)\end{array}$ & $\begin{array}{c}5,25 \\
(5,54)\end{array}$ & $\underline{2,27}$ & $\underline{0,02}$ \\
\hline $\mathrm{NO}_{2}^{-}$ & & $\begin{array}{c}0,084 \\
(0,026)\end{array}$ & $\begin{array}{c}0,312 \\
(0,311)\end{array}$ & $\underline{-3,42}$ & $\underline{0,00}$ & $\begin{array}{c}0,116 \\
(0,026)\end{array}$ & $\begin{array}{c}0,384 \\
(0,394) \\
\end{array}$ & $-3,42$ & $\underline{0,00}$ \\
\hline
\end{tabular}

${ }^{1}$ Underlined type indicates significant differences $(\alpha=0.05)$.

Water temperature at both points closely depended on air temperature, and therefore, it was statistically higher in the summer season. Concentration of dissolved oxygen and oxygen saturation also strongly correlated with air and water temperature. Mean and median values of these parameters were significantly higher at both measurement-control points in the winter season (Table 2, Figure 2), as lower air temperature is known to promote oxygen solubility in water.

According to Dojlido [1995], the lowest concentration of phosphates in clean waters is observed in the summer and the highest in the winter, being associated with inhibition of vegetation and lack of phosphate assimilation by plants in winter. Analyses performed for the samples collected at the mouth of the river revealed some deviations from this rule, as similar concentrations of $\mathrm{PO}_{4}^{3-}$ were recorded for both seasons. This natural cycle of phosphate concentration changes was severely disturbed by pollutions reaching point 2 , where significantly higher phosphate levels were determined in the summer (Table 2, Figure 2).

The lowest concentration of ammonium nitrogen is usually recorded in the periods when high temperatures are prevailing, as it is then absorbed by plants and undergoes nitrification [Dojlido 1995]. This natural trend was observed in the point 1 , where the concentration of ammonium nitrogen was significantly lower in the summer. In the water reaching Maszkienice, mean and median concentration of $\mathrm{N}-\mathrm{NH}_{4}^{+}$was similar in both periods of the year, suggesting a supply of pollution, probably from point sources. The same dynamics of seasonal changes was also observed for total nitrogen (Table 2, Figure 2). 
Oxygen saturation degree [\%]

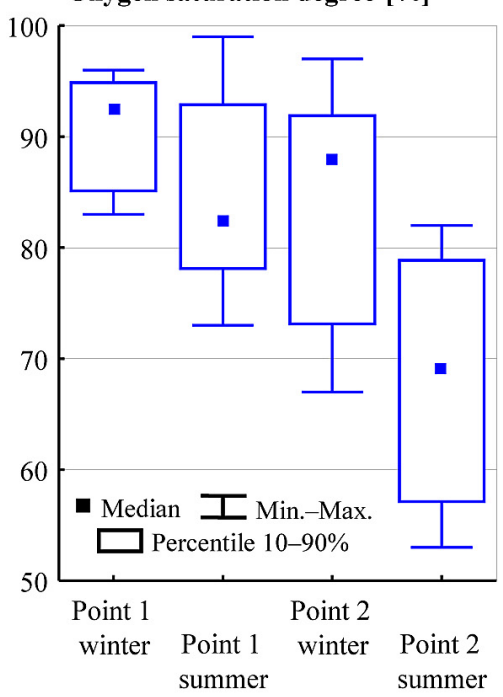

Phosphates $\left[\mathrm{mg} \cdot \mathrm{dm}^{-3}\right]$

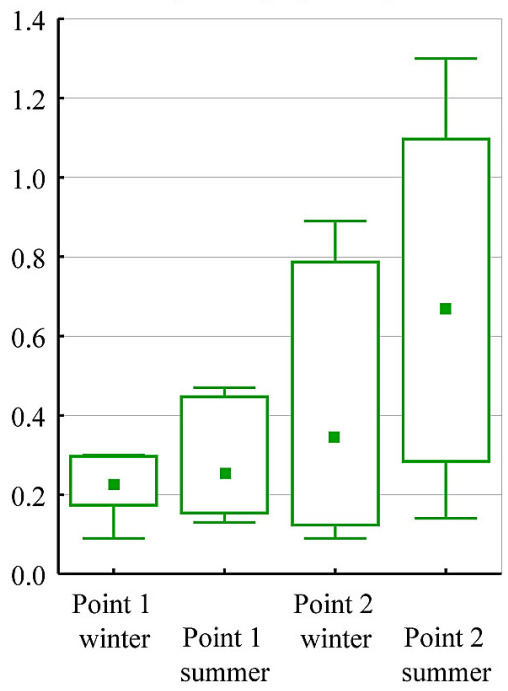

Ammonia nitrogen $\left[\mathrm{mg} \cdot \mathrm{dm}^{-3}\right]$

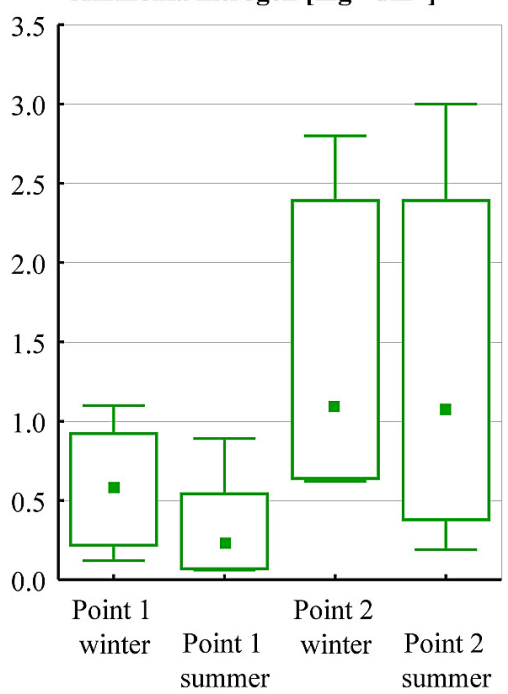

$\mathrm{BZT}_{5}\left[\mathrm{mg} \mathrm{O} \mathrm{O}_{2} \cdot \mathrm{dm}^{-3}\right]$

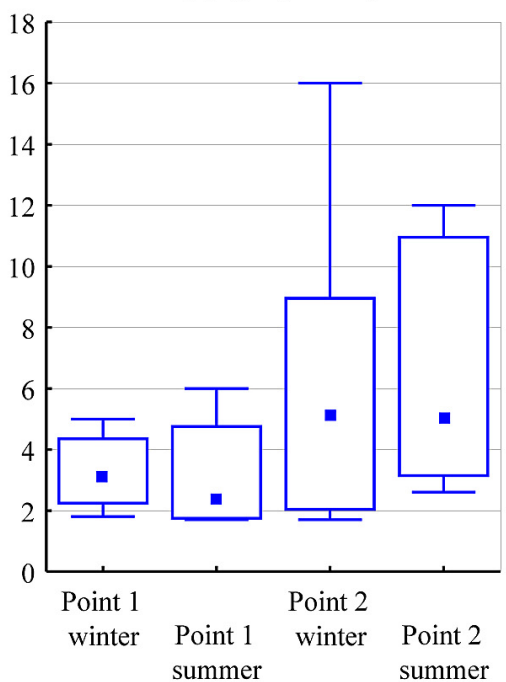

Total nitrogen $\left[\mathrm{mg} \cdot \mathrm{dm}^{-3}\right]$

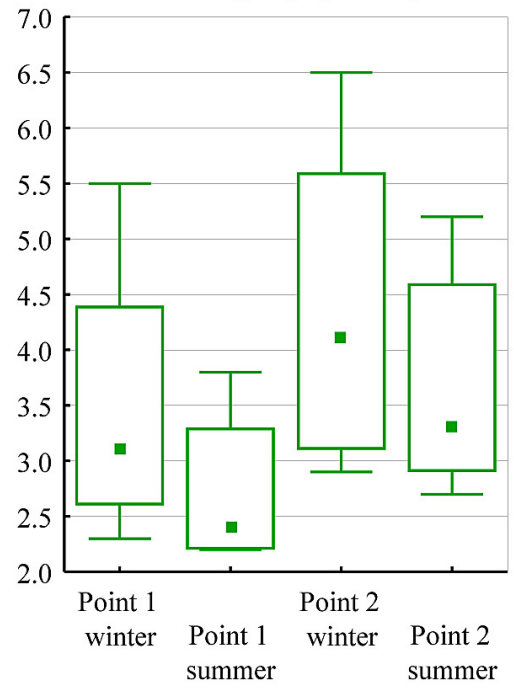

Nitrate nitrogen $\left[\mathrm{mg} \cdot \mathrm{dm}^{-3}\right]$

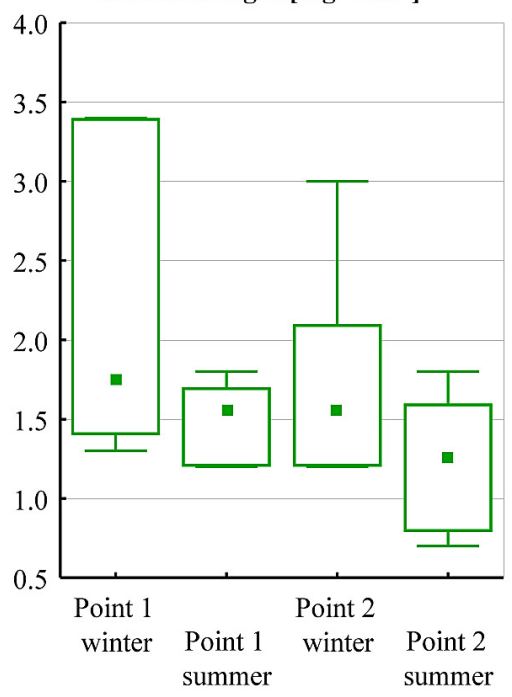

Number of point and half-year
Total organic carbon $\left[\mathrm{mg} \mathrm{C} \cdot \mathbf{d m}^{-3}\right]$

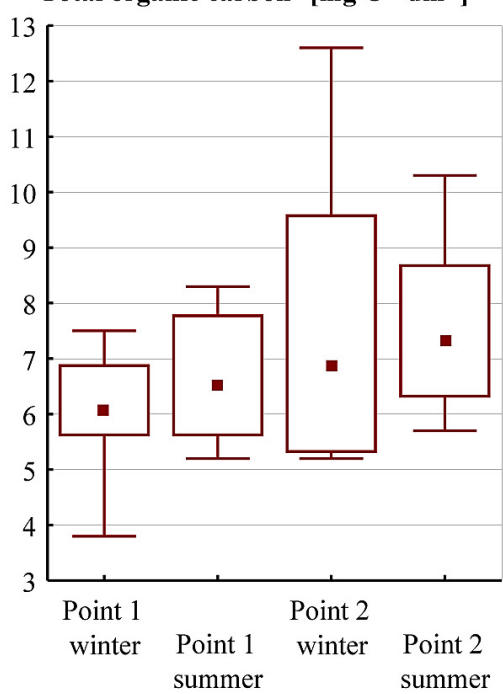

Kjeldahl nitrogen $\left[\mathrm{mg} \cdot \mathrm{dm}^{-3}\right]$

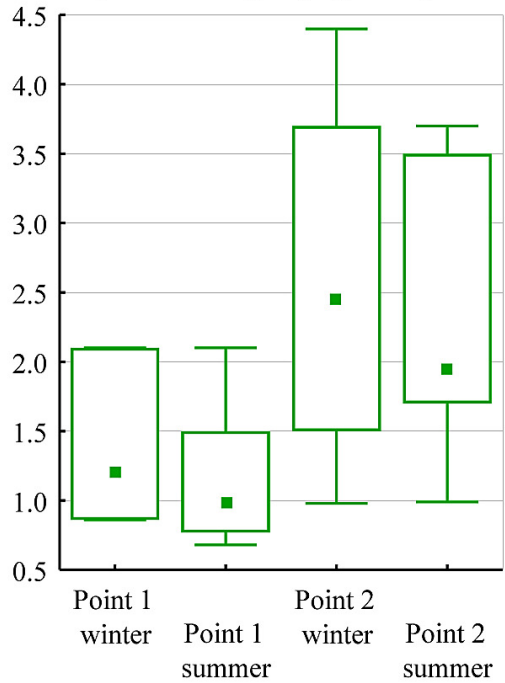

Nitrites $\left[\mathrm{mg} \cdot \mathbf{d m}^{-3}\right]$

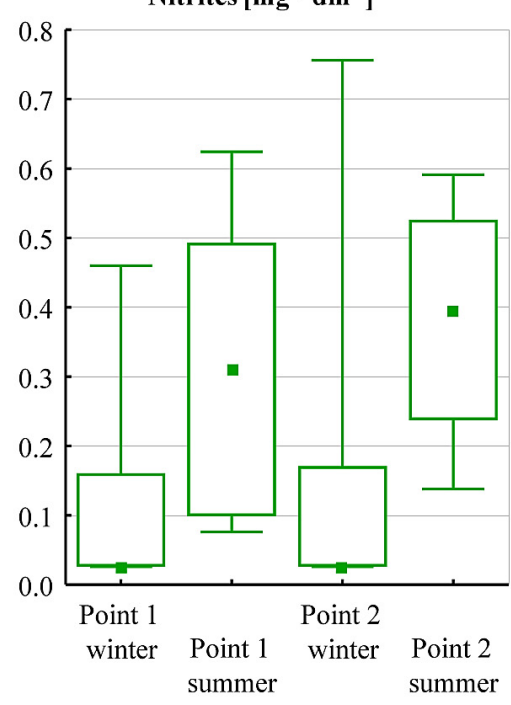

Figure 2. Seasonal variability of selected water quality indices in the Uszwica river 
Table 3. Assessment of water usability as a natural fish habitat and eutrophication risk

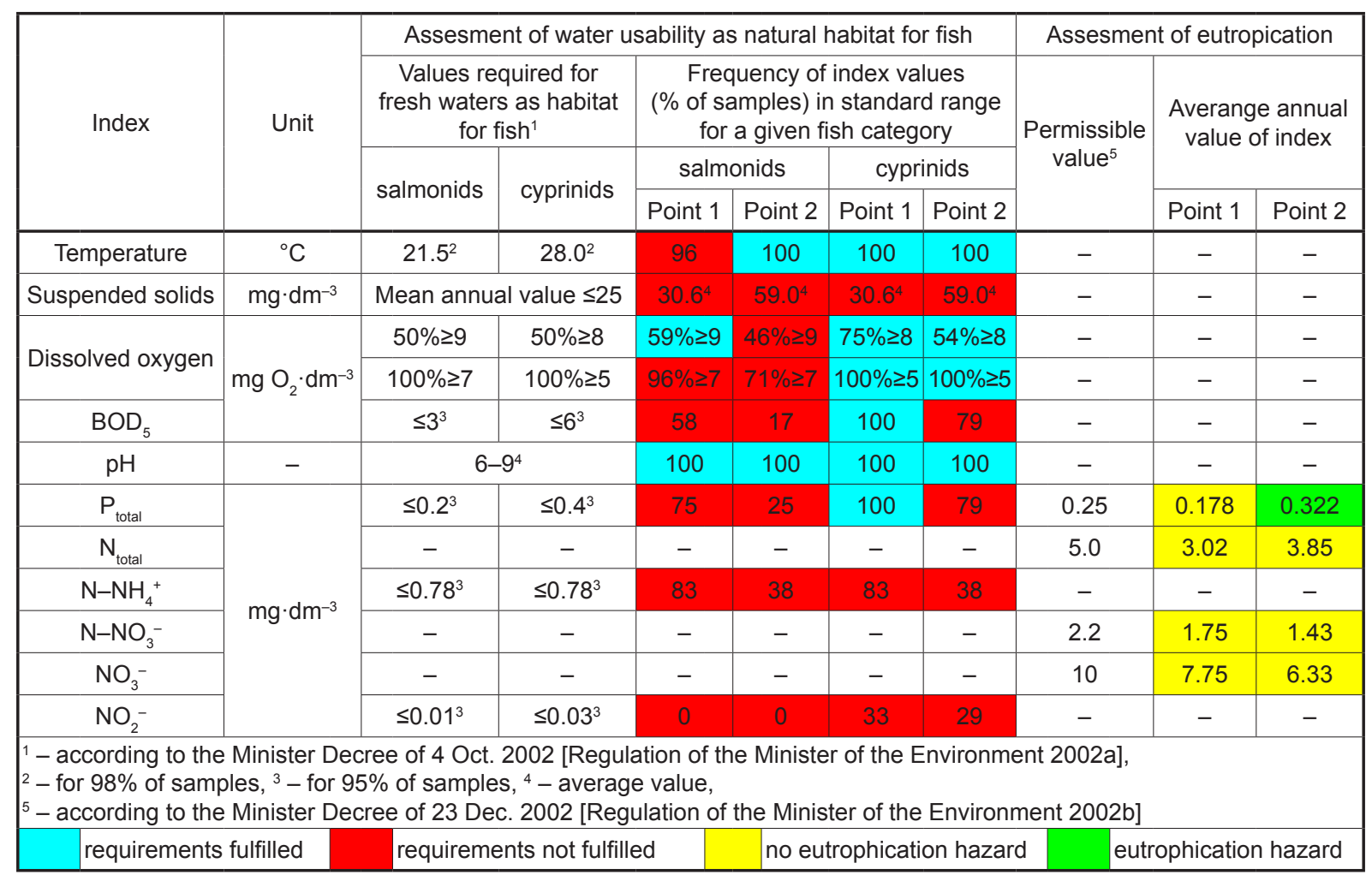

In the summer, concentrations of nitrate nitrogen and nitrates were significantly lower along the entire length of the Uszwica (Table 2, Figure 2) than in the winter. This indicates a natural seasonal variability of these biogenic indicators, involving their reduced content in water due to absorption by plants during the growing season [Dojlido 1995].

Nitrites, intermediates generated as a result of ammonium nitrogen oxidation, are usually present in larger quantities during the summer, which is associated with higher nitrification intensity at higher temperatures [Dojlido 1995]. The present study revealed that this natural trend was maintained at both measurement-control points (Table 2, Figure 2).

Due to high concentration of total suspended solids, ammonium nitrogen and nitrite, the Uszwica waters evaluated in the years 2011-2012 upstream of both measurement-control points did not meet the requirements of natural habitats for salmonids and cyprinids. Additionally, concentration of $\mathrm{BOD}_{5}$ and total phosphorus were too high at Maszkienice point but they were decreasing along the course of the river and finally complied with habitat requirements for salmonids and cyprinids at the point 1 . Water temperature analysis revealed that, except for a single case of exceeding the critical temperature for salmonids $\left(21.5^{\circ} \mathrm{C}\right)$ at the mouth of the river, the waters were in general cold enough for both types of fish. In the upper course, oxygen conditions were conductive only to cyprinids but oxygen concentration increased along the river until it finally met the requirements for salmonids as well (Table 3 ).

The Uszwica water upstream from Maszkienice was considered eutrophic, as the permissible mean annual concentration of total phosphorus $\left(0.25 \mathrm{mg} \cdot \mathrm{dm}^{-3}\right)$ was exceeded by $29 \%$ (Table 3 ).

\section{CONCLUSIONS}

1. Water flowing via developed areas was significantly less saturated with oxygen and contained higher amounts of suspended solids, organic matter and nutrients, as compared to the water crossing mainly used agricultural areas. Therefore, the ecological potential of the river was considered good in its lower course and poor upstream from point 2 in Maszkienice.

2. Disturbances in seasonal concentrations of phosphates, total nitrogen and ammonium nitrogen indicated high degree of water pollution in the middle course of the Uszwica. However, due to intense self-purification, wa- 
ter quality in the lower course was similar to that in natural conditions.

3. High concentration of total suspended solids, ammonium nitrogen and nitrate made the Uszwica water unfavorable for salmonids and cyprinids, however, much better conditions occurred at the mouth of the river.

4. Due to high concentration of total phosphorus, water upstream of Maszkienice was considered euthrophic.

5. The analyses performed under this study revealed that despite numerous activities aimed at reducing water pollution in Poland, the risk of not meeting the objectives of achieving good status of surface waters, set out the Water Framework Directive, is considerable in many river catchments.

\section{REFERENCES}

1. Bogdał A., Kanownik W., Wiśnios M. 2012. Zmiany wartości i stężeń fizykochemicznych wskaźników jakościowych wód rzeki Prądnik-Białucha (Wyżyna Krakowsko-Częstochowska). Gaz, Woda i Tech. Sanit., 8, 358-361.

2. Bogdał A., Ostrowski K. 2009. Loads of selected components supplied with precipitation and flowing away from the area of two small catchments with diversified use. Acta Sci. Pol., Form. Circ., 8 (1-2) 2009, 35-45.

3. Chełmicki W. 2001. Woda. Zasoby, degradacja, ochrona. PWN, Warszawa.

4. Dąbrowska J. 2008. Ocena zawartości związków azotu i fosforu w wodach rzeki Trzemny. Infrastruktura i Ekologia Terenów Wiejskich, 7, 57-68.

5. Directive 2000/60/EC of the European Parliament and of the Council establishing a framework for Community action in field of water policy. OJ L 327, 21.12.2000.

6. Dojlido J. R. 1995. Chemia wód powierzchniowych. Wyd. Ekonomia i Środowisko, Białystok.

7. Húska D., Krupová K., Halaj P. Mandalová K. 2013. Ewaluation of surface water Žitava catchment under the aspect of anthropogenicimpact. Acta Sci. Pol., Form. Circ., 12 (3), 41-51.

8. Kanownik W., Kowalik T., Bogdał A., Ostrowski K., Rajda W. 2011. Jakość i walory użytkowe wody potoku Szczyrzawy. Zesz. Prob. Post. Nauk Rol., 561, 65-81.

9. Kanownik W., Rajda W. 2011. Samooczyszczanie wody potoku Pychowickiego. Zesz. Prob. Post. Nauk Rol., 561, 81-91.
10. Kleiber T. 2012. Pollution of the natural environment in intensive Cultures Under Greenhouses. Arch. Environ. Prot., 38 (2), 45-53.

11. Kowalik T., Bogdał A., Kanownik W., Borek Ł. 2012. Sezonowość zmian wartości wybranych właściwości fizykochemicznych wody odpływającej z małej zlewni rolniczo-leśnej. Gaz, Woda i Tech. Sanit., 8, 354-357.

12. Lampart-Kałużniacka M., Wojcieszonek A., Pikuła K. 2012. Ocena stanu ekologicznego wód rzeki Regi na odcinku w obszarze miasta Gryfice. Annual Set The Environment Protection - Rocznik Ochrony Środowiska, 14, 437-446.

13. Moniewski P., Stolarska M. 2007. Wpływ naturalnych i antropogenicznych czynników na podstawowe charakterystyki fizykochemiczne wody w małej zlewni strefy podmiejskiej Łodzi. Woda Środ. Obsz. Wiej., 7, 1 (19), 105-122.

14. Napieralska A., Gołdyn R. 2013. Sanitary Analyses of Runoff Water a River. Pol. J. Environ. Stud., $22,2,481-486$.

15. Ostrowski K., Rajda W., Bogdał A., Policht A. 2005. Wpływ zabudowy miejskiej na jakość wody w potoku podgórskim. Zesz. Nauk. AR Kraków nr 420, Inż. Środ. 26, 21-29.

16. Pokładek R., Nyc K. 2008. Ocena zasobów wodnych i ładunków wybranych składników chemicznych odprowadzanych z obszaru zmeliorowanej małej zlewni rolniczej. Zesz. Probl. Post. Nauk Roln., 532, 211-222.

17. Policht-Latawiec A., Bogdał A., Kanownik W., Kowalik T., Ostrowski K. 2015. Variability of physicochemical properties of water of the transboundary Poprad river. Journal of Ecological Engineering, 16, 1, 100-109.

18. Policht-Latawiec A., Bogdał A., Kanownik W., Kowalik T., Ostrowski K., Gryboś P. 2014. Jakość i walory użytkowe wody małej rzeki fliszowej. Annual Set The Environment Protection - Rocznik Ochrony Środowiska, 16, 546-561.

19. Rozporządzenie Ministra Środowiska z dnia 4 października 2002 r. w sprawie wymagań, jakim powinny odpowiadać wody śródlądowe będące środowiskiem życia ryb w warunkach naturalnych. Dz. U. Nr 176, poz. 1455. 2002a.

20. Rozporządzenie Ministra Środowiska z dnia 23 grudnia 2002 r. w sprawie kryteriów wyznaczania wód wrażliwych na zanieczyszczenia związkami azotu ze źródeł rolniczych. Dz. U. Nr 241, poz. 2093. 2002 b.

21. Rozporządzeniem Ministra Środowiska z dnia 15 listopada 2011 r. w sprawie form i sposobu prowadzenia monitoringu jednolitych części wód powierzchniowych i podziemnych. Dz. U. Nr 258, poz. 1550. 2011. 
22. Rozporządzenie Ministra Środowiska z dnia 30 października 2014 roku w sprawie sposobu klasyfikacji stanu jednolitych części wód powierzchniowych oraz środowiskowych norm jakości dla substancji priorytetowych. Dz. U. z 2014 r. poz. 1482. 2014.

23. Wiatkowski M., Rosik-Dulewska Cz., Gruss Ł.
2012. Profil zmian wskaźników jakości wody w rzece Stobrawie. Infrastruktura i Ekologia Terenów Wiejskich, 3, 21-35.

24. Żmuda R., Sasik J., Szewrański Sz. 2001. Odpływ wybranych składników i materii ze zlewni rolniczej Wzgórz Trzebnickich. Zesz. Nauk. AR Krak, Inż. Środ., 21, 41-47. 